\title{
Marketing Activities of Local Food Producers in E-Commerce
}

\author{
Grzegorz Szymański
}

Citation: Szymański, G. Marketing Activities of Local Food Producers in E-Commerce. Sustainability 2021, 13, 9406. https://doi.org/10.3390/ su13169406

Academic Editors: Maria

Pilar Martinez-Ruiz,

Alicia Izquierdo-Yusta and

Riccardo Testa

Received: 30 June 2021

Accepted: 18 August 2021

Published: 21 August 2021

Publisher's Note: MDPI stays neutral with regard to jurisdictional claims in published maps and institutional affiliations.

Copyright: (C) 2021 by the author. Licensee MDPI, Basel, Switzerland. This article is an open access article distributed under the terms and conditions of the Creative Commons Attribution (CC BY) license (https:/ / creativecommons.org/licenses/by/ $4.0 /)$.
Department of Management and Production Engineering, Lodz University of Technology, 90-924 Lodz, Poland; grzegorz.szymanski@p.lodz.pl

\begin{abstract}
The food industry is characterized by a constant increase in value. The purpose of this study is to identify the most popular marketing forms used by the analyzed enterprises, which were food producers selling online among the local community and identification of the correlation of the analyzed variables with the age of companies. The survey was carried out with the use of the CATI (Computer Assisted Telephone Interviewing) method, and the research tool was a questionnaire. The Chi-square statistics was used to examine the dependencies of individual variables and V-Cramer coefficient was used to identify the strength of the correlation. The obtained results and their analysis enable to conclude that there is a strong relation between the number of encountered problems in conducting online sales and the period of the company's existence. The relationship (with a moderate strength) between sources of marketing inspirations used in e-stores and the company's age was also confirmed. Furthermore, it was noticed that the number of marketing tools increases with the period of the company's existence. Sales promotion, social media marketing and website positioning were indicated among the most popular tools.
\end{abstract}

Keywords: e-commerce; marketing activities; food producers; local food

\section{Introduction}

The food industry in Poland is characterized by a constant increase in value. This is one of the sectors that quickly recovered after the crisis connected with the political transformation in Poland in the 1980s. Currently, according to the Polish Classification of Products and Services (PKWiU), the "food products" division has the largest share in the value of sold goods (16.8\%)-its value amounts to 200 billion PLN [1]. Furthermore, this industry is a leader in terms of innovation-not only in Poland, but also in the EU countries [2]. During the last decade, discount stores recorded the greatest increase in sales. They increased their value fivefold. This fact along with the dynamic development of e-commerce contributed to the decline in traditional food trade. Discount stores gained their position thanks to an adequate assortment and marketing strategy.

Implementation of innovations is very often an effective strategy for achieving sustainable development in this industry [3,4]. The success of introducing innovations in the field of products and processes in the food industry (especially in small food companies) is often the result of the marketing abilities presented by entities [5,6]. Marketing activities in contemporary globalization, computerization and the dissemination of social media are designed to increase the awareness of consumers and enable them easy and quick access to the necessary knowledge about food products [7].

Marketing activities and strategies of enterprises in the food sector should strive to consumer satisfaction. They should be permanently adapted to changing trends, changes in consumption, as well as they ought to include activities taken in countries with high, middle and low income [8]. Taking into account the e-commerce sector, the type of electronic devices used by customers should be considered-i.e., their parameters such as screen size, resolution and interactivity. They can affect the reactions of consumers to the marketing content [9]. 
The importance of the food industry, and more precisely food producers in the concept of sustainable development, is emphasized by studies indicating a large waste presented by both consumers and producers. The findings show that processing is by far the most important food loss hotspot ([10], p. 47). The very concept of sustainable development and its meaning are known to employees of the food industry. Therefore, many enterprises implement procedures for the management of sustainable development activities [11]. On the other hand, the advantage of local small food producers is often the lack of consumer confidence in the quality of food offered by international corporations. Worldwide food scandals, e. g., Chinese melamine-adulterated milk (2008), horse meat in European countries (2013) and fipronil-contaminated eggs from the Netherlands (2017) increase consumer attention to food quality issues. Consumers want to receive more information about farming, processing and even marketing activity ([12], p. 2). Popularization of the concept of sustainable consumption is also a factor that positively influences the increase in sales of local food. The attitude of consumers (i.e., selection of places, where they buy domestic products) significantly contributes to the development of their region. Online clients have different needs than traditional ones. A particular demanding group consists of young people (up to 24 years of age) [13] (p. 10). Therefore, an appropriate understanding of the needs and expectations of recipients is an important element of effective marketing activities.

Considering the data obtained from the Scopus database for a search carried out with the following topic, abstract and keyword "food marketing", it can be seen that the number of documents has increased from 1975 until today. A particularly large increase in the number of publications has been recorded in recent years, in 2019 this number reached the value of 109 and in 2020-120. This context shows that the selected topic is becoming more and more popular.

One of the problems for the development of domestic food producers is the fact that local products are more and more often withdrawn from the offer of many foreign retail chains. Currently, up to $80 \%$ of products (excluding bakery products) offered in retail trade are manufactured by international corporations. The last categories, in which Polish producers have a significant position, are dairy products and sweets. In the conditions of trade liberalization (leading to the increased competition between food producers), competitiveness is growing in both international and national markets [14] (p. 13).

As marketing is one of the most important activities in the e-commerce sector, the food industry is characterized by a steady increase in value, hence the study of these important aspects. The variety and popularity of individual marketing activities in the context of e-commerce remains to be explored, especially depending on the age of the companies. Therefore, it is imperative that scientists and practitioners to comprehend the influence of company age on the use of selected forms of marketing, which is the main focus of this study. The results of an analysis of global literature, which are presented later in this article, revealed a research gap. The current study takes into account this research gap and identifies trends in marketing activities and dependencies in the e-commerce industry. Following the abovementioned gap, this study assessed how the age of food producing companies affects the size of the product range, marketing activities, sources of marketing inspiration and additional sales channels. This gap concerns all the more the importance of ages company in terms of marketing activities in the abovementioned areas.

Therefore, this study was conducted in order to solve the following research problem: what is the importance of the age of companies, which are food producers selling online among the local community, depending on the selected aspects indicated as important based on the literature analysis below. However, studies that would directly measure the impact of the company's age [15-19], on the variety of marketing activities are very rare and typically touch this aspect just indirectly, especially among food producers [20]. Some researchers also studied other factors related to marketing activity, including sources of marketing inspirations [21-26], additional sales channels [27-34], variety of sales offer [35-41] and problems and barriers in online selling [42-45]. These areas of research continue to evolve and are developed in the scientific literature, resulting in a rapid increase in both 
theoretical and research interest. However, all these elements were not included together in the research on the presented problem, which creates a research gap and confirmation of the problem's novelty. Identification of the indicated elements of marketing activities used by food producers, in the context of the company's age, can contribute to the development of the theory of managers' behavior in relation to the selected industry and can introduce some management implications for decision makers.

The outline of the paper is as follows: The literature review was divided into areas related to the identified aspects as relevant to the research problem and presented with hypotheses in Section 2. Section 3 is dedicated to the presentation of materials and research methods. The research results are presented with discussion in Section 4. Finally, the conclusions, theoretical and practical contributions, and limitations of this study and further research are included in Section 5.

\section{Literature Review}

With the constant development of e-commerce, it is natural for barriers that limit dynamics to appear. Various studies indicate the existence of various barriers and problems faced by e-commerce companies. The basic barriers slowing down the full use of the Internet in the e-commerce sector include [33,46-49]: customer service, distribution and logistic service, payment processing, infrastructure, economic situation, fiscal and legal matters and marketing.

Online food sales are still not very popular, not only in Poland [50]-despite the fact that e-commerce reduces transaction costs, eliminates geographical barriers existing in traditional trade and enables to purchase 24 hours per day (without the need for a personal visit to the store) [51]. However, in the sector of food products, there is greater concern (than in other sectors) about the quality of the online products. Moreover, fresh goods may be damaged during delivery - this causes the increasing number of returns [52]. Problems with quality and a large number of complaints are often connected with such food products as bread, cheese or frozen food [53]. This phenomenon is smaller among food producers, who sell products mainly to local recipients, because the time and delivery route are much shorter. There is no need to prepare a specialized route for delivery vehicles in the case of perishable food [54]. The growing popularity of online food trade sometimes requires a stimulus-for example, a random event [55] such as the global problem of COVID-19 epidemic [56]. The conditions connected with the COVID-19 encouraged (and sometimes even forced) to activate and scale e-commerce platforms in the food sector. Moreover, they prompted consumers to increase their interest in this form of purchasing food products. Some enterprises operating in the delivery area recorded a sales increase of up to $500 \%$ compared to April 2020 [57]. Furthermore, it is estimated that electronic sales of food will increase by approx. 40\% in 2021 and that the e-commerce sector will continue to grow dynamically after the end of the pandemic [58]. Despite the fact that the COVID-19 crisis affects various industries ([59], p. 12), it seems that enterprises operating in the e-commerce sector are much more resistant to the negative effects of the contemporary situation. Currently, 30\% of Polish internet users declare that in the last 12 months they have bought a food product from an online store [60] (p. 159).

An important aspect in the described analysis is the definition of the concept of locality of food producers, which is usually referred to the geographical range. However, it is not possible to indicate a specific size of the area due to the large variation in the size of agricultural areas depending on the structure, economic development and agricultural policy in countries. A much more optimal solution is to adopt the administrative boundaries of municipalities or voivodeships as a classifier of a local food producer [61]. A "local product" sometimes means products belonging to a specific geographic region or area, which owe their popularity and quality to the natural conditions and touristic features of a certain area. Traditions and characteristic cultures, as well as products, which have been produced via the promotion of the economic development of the area or which use raw materials and resources specific to the area of production, are equally important [62]. The 
locality is more broadly interpreted as national products that usually become traditional and often legally protected recipes. This applies to, inter alia, Jidori chicken, which has become the leading symbol of local food in Japan [63]. Some approaches indicate locality as a comprehensive system of cooperation between local authorities and entrepreneurs [64].

The analysis of the literature shows that the adopted subject of the study is attractive, interesting and is an important research area today. However, most publications on marketing in the food area focus on their impact on the audience, especially children and adolescents [65-67]. Marketing activities undertaken by food producers selling their products locally are also not very popular research area. A local seller should take into account different marketing elements and tools than the manufacturer offering its products in hypermarkets and distribution networks. Therefore, the analysis of marketing activities carried out by food producers selling products both in the e-commerce sector may supplement the theoretical gap in the analyzed scope.

The research results and analysis are to provide the necessary information on the methods and tools supporting marketing activities among food producers. Thus, supporting the discussion on the possible influence of the food manufacturer's age on the forms of marketing used. It also provides information that may be valuable for decision-makers in the process of planning marketing strategies among the analyzed enterprises.

Taking into account the analysis of the literature, it was determined that the aim of the publication is to identify the most popular marketing forms by the analyzed enterprises, which were food producers selling online among the local community. Additional goals are the analysis of the correlation between the company's age and selected areas of activity, such as: problems with online sales, additional sales channels and sources of inspiration for planning marketing activities.

\subsection{Marketing Activities}

In the area of marketing, social media marketing plays an important role [68]. It is correlated with content marketing activities [69,70]. The growing general interest and the number of social media users also contributed to the increase of the effectiveness of messages in the area of food products [71]. Social media and websites are the main channels for communicating information about the characteristics of individual food products. The majority of recipients of marketing messages understand the main information. They find them helpful in gaining more information about health benefits. The research has shown that higher level of understanding of the messages causes higher level of distrust of marketing messages (they consider them as misleading messages) [72]. Furthermore, social media and the food content presented in this media have negative impact on consumption behaviors and are linked to non-sustainable food behavior. Moreover, they tend to create homogenized consumption, which is often the primary factor in environmental degradation [73]. The advantage of using social media in marketing activities of food products is the possibility of using text, video and voice message at the same time [74].

One of the key reasons for the low demand for organic food is a poorly informed consumer due to the lack of insufficient promotion of organic products [75]. Better informed consumers are even more likely to support the use of biotechnology in food production than those, who are less informed [76].

Due to the wide coverage, TV advertising is often used in marketing strategies in the area of food products [77-79]. The number of TV commercials with food products is very large-for example, among over 800,000 commercials registered in Australian television in $2016,11 \%$ were related to food $(n=97,837)$. The most frequently advertised products were snacks, cold cuts, fast food, take-away dishes and sweetened drinks [80] (p. 962). The impact of TV commercials on the sales of food products has been proven not only in terms of increasing sales, but also as psychological stimuli to increase appetite [81]. The vast majority of food advertisements presented on TV contain at least one strategy influencing the viewer's beliefs. Persuasive marketing is defined as a set of actions that persuade 
consumers to buy a product (based not only on rational factors, but especially on emotional and sentimental ones) [82] (p. 1069).

On the one hand, there are many social marketing concepts and trends aimed to encourage adequate healthy eating behavior [83]. However, there are also marketing activities aimed only at increasing the sale of promoted food products-without paying attention to the health of consumers, the process of sustainable development or even the young age of recipients $[84,85]$. The vast majority of food marketing activities are not aimed at promoting healthy food. They concern products with high energy value, which are poor in nutrients $[86,87]$. There is an increasing number of food advertisement targeting children, who are more sensitive to advertising messages than adults [88,89]. A related aspect is also the inspiration to implement appropriate marketing activities by companies. As inspiration, a behavioral concept is taken, which is defined as the process of being inspired to do something [90]. In the area of marketing activities, inspiration is defined as a source of obtaining information on the choice of the forms of marketing used. Therefore, I propose the following hypothesis:

Hypothesis 1 (H1): The age of companies has a positive impact on applied marketing forms.

\subsection{Company's Life Cycle}

One of the key factors identifying the development of companies is age, which often indicates experience, more effective entrepreneurship [91] (p. 256), greater competitiveness, as well as greater market valuation and less profitability uncertainty [92,93]. Age is also considered an important determinant of a company's innovation because of the existence of learning outcomes which allow mature companies to innovate more effectively as they rely on previous routines, experience and skills [15], also in the food industry [20]. The company's age is closely related to the concept of the company's life cycle. Companies experience different stages such as entrepreneurship, growth, maturity, and recession. Enterprises at different stages will have different characteristics, experiences and various risks [16] (p. 1170). Young and growing companies have uncertain operating environment sandless in formative earnings. Young company managers are probably less customerfocused due to less effective communication [17] (p. 71). In the growth cycle, external financial barriers emerge. There are also significant tax burdens related to the expansion of the company's scale of operations. Staffing problems are also important and decide about the further development of companies [18]. The last cycle includes decentralization, changing the organizational and market structure, rebuilding the business, and adapting to changed conditions [19] (pp. 35-37). The company's age, which represents the company's life cycle, is used as an independent variable in the study.

\subsection{Sources of Marketing Inspirations}

Nowadays, clients are one of the most important sources of information used in designing marketing strategies. On the Internet, customers deal with information in three situations: searching-where the customer is looking for specific information, sharingwhere customers pass on information received from others, and providing-where customers create information and make it available on the Internet for other [21]. The studies also found that there is a correlation between the lifestyle of the respondents and the elements of the marketing offer that clients would like to co-create with the bidders [24]. Marketers should identify the factors that influence online customer behavior, as well as the relationships between these factors, to create new effective marketing strategies and acquire new e-commerce customers [25]. In e-commerce platforms, not only companies, but also customers expect information and advice on products from other customers that help solve problems or make informed purchasing decisions [26]. Marketing managers in the e-commerce sector require precise data and research on consumer behavior to make strategic decisions. 
Employees are another frequently used source of information. It is estimated that approx. 70-80\% of information that a company needs comes from employees who collect it during their contacts with the company's suppliers, business partners and customers [21]. Competitors themselves are an important source of marketing information. A variety of information can be obtained from competitors by following their social media activities, visiting and consulting their sellers, and buying competitors' products. Also the annual reports of the competition do not contain trade secrets, they show the strengths and weaknesses of the competition [22]. The media in the modern world has an impact on every area of business, especially in the e-commerce sector. The development of modern technologies and the popularization of social media certainly favor a wide spectrum of media influence on advertising activities. According to the InternetStandard report [26], competition and customers are the most frequently used elements as inspirations for marketing activities in e-commerce. Conferences/workshops and media are the least used sources.

Hypothesis 2 (H2): The age of companies has a positive impact on sources of marketing inspirations.

\subsection{Additional Sales Channels}

In recent years, many countries have experienced a large increase in online sales, generating a demand for delivery services, mainly to homes. Some sellers use a coordinated two-channel strategy (i.e., both online and offline), while others focus on selling through traditional offline channels. Other companies are switching to online channels only, but such a strategy is unlikely in industries where retailers have invested money in assets related to traditional distribution [33]. However, companies that use the online sales channel have better overall results and higher sales compared to companies that are not interested in selling online [34].

For companies, websites (as an advertising tool) constitute an additional and increasingly popular communication channel with customers. The websites offer a new sales channel in order to expand the reach of small local businesses. Therefore, websites are an attractive sales channels for food products [27]. An additional advantage is the highest (among the forms of communication) credibility of the presented information-in the opinion of clients [28]. The quality of e-commerce platforms affects the purchasing intentions of potential clients [29-31]. Therefore, their adequate design (in accordance with the latest trends) and the use of mechanisms of psychological influence and management of consumers' emotions are very important [32]. The security of data, delivery and electronic payments is also significant [94] (p. 387). Therefore, the following hypothesis is proposed:

Hypothesis 3 (H3): The age of companies has a positive impact on additional sales channels.

\subsection{Number of Offered Products in E-Shops}

Traditional marketing believes that the more choices a seller offers to a customer, the better the effect, because the greater the variety of goods, the faster the choice [40]. Econsumers appreciate the benefits of the variety of products available, and the large number of products significantly contributes to greater satisfaction, a better attitude to online shopping and greater loyalty to the store [35]. A larger assortment increases customer satisfaction because it increases the probability of a perfect match between customer preferences and product variants [36,37]. On the other hand, making choices with a large number of options requires more cognitive effort, which may result in a cognitive deficit. Sometimes customers who have more choices, they buy less. In the decision-making process, people often simplify by using the wrong criteria. More choices can lead to more dissatisfaction [38,39]. With fewer products offered online, consumers find it easier to process product information and compromises and comparisons are less difficult [41]. The aforementioned literature suggests a relationship between the number of products offered 
and customer satisfaction. Therefore, I propose to examine the influence of the company's age (experience) on the number of products offered:

Hypothesis $4 \mathbf{( H 4 ) : ~ T h e ~ a g e ~ o f ~ c o m p a n i e s ~ h a s ~ a ~ p o s i t i v e ~ i m p a c t ~ o n ~ n u m b e r ~ o f ~ p r o d u c t s ~ o f f e r e d . ~}$

\subsection{Problems in Online Selling}

The problems faced by companies selling on the Internet depend on many factors, such as the industry, the state of IT infrastructure in the country [45], the economic situation as well as legal, sociopolitical and financial changes [43,49]. For example, logistics and shipping services are the most important challenges facing e-commerce companies in India [42]. In Brazil, the lack of an appropriate legal and regulatory environment to support e-commerce has been a significant obstacle [44]. Other research reveals that online retailers are poised with myriad of inventory management, such as demand fluctuations, reverse logistics, and stock outs [95]. However, the most difficult barrier and challenge is customer satisfaction. Meeting the increasingly high expectations of customers in e-commerce is a significant problem for today's companies. The variety of challenges and barriers occurring in e-commerce and the analysis of the above-mentioned literature is the basis for introducing:

Hypothesis 5 (H5): The age of companies has a positive impact on problems in online selling.

\section{Materials and Methods}

The results of the research presented in this article were prepared from a survey carried out among 200 small and medium-sized enterprises, operated in the e-commerce sector in Poland in 2020. The questions concerned the year 2019. All companies were contacted by e-mail or telephone and invited to take part in the study. Upon receipt of the confirmation of participation, companies were asked to identify one appropriate employee and asked for his contact details. In this group, 30 entities were involved in the production and trade of food products among the local community. Companies focused their activities on the local area of the commune. To increase the sample, an additional 23 companies were surveyed in 2021. This process led to a sample of 53 appropriate companies for final analysis. Purposive sampling was used in the study. The necessity of purposeful selection resulted from the basic criterion, which was the lack of a sampling frame, i.e., the lack of a database of food producers selling online, which would allow random selection. The survey was conducted with the use of the Computer Assisted Telephone Interview (CATI) method. The research tool was a questionnaire prepared by the author of this publication. The questionnaire has been composed of two parts: sociodemographic profile of companies and the declarative research part concerning forms and marketing activities. The respondents were people responsible for marketing activities in the analyzed companies: owners, marketing managers and people managing teams dedicated to marketing activities. To ensure that each questionnaire was completed by a user with a marketing function in the enterprise, these conversations were recorded, with the consent of the respondent.

The CATI method is a popular type of test used in the field of management sciences, with the sample containing enterprises from the SME sector [96] (p. 10) and marketing area [97]. The questionnaire consisted of closed questions and it was addressed to people responsible for marketing actions in a given enterprise. A nominal scale with multiple-choice questions was used in the questionnaire. Bearing in mind the correct design and realization of the research process, and then the interpretation of the obtained results, the analysis of the literature in the field of marketing research was performed. Moreover, the design of the questionnaire was based on the results of two previous studies-one preliminary study by the author and a national survey on the e-commerce sector in Poland [26]. As a consequence, these activities made it possible to identify an adequate research method and a tool-appropriate from the point of view of the analyzed research issues and the adopted 
group of respondents [98-100]. Table 1 shows the characteristics of the research procedure adopted in order to achieve the purpose of study.

Table 1. Basic information on the conducted survey.

\begin{tabular}{cc}
\hline Specification & Characteristics \\
\hline research methodology & CATI (computer assisted telephone interviewing) \\
\hline respondent & employee responsible for marketing activities \\
\hline sample selection & purposive selection of typical units \\
\hline sample size & 53 (companies) \\
\hline geographical scope & Poland \\
\hline time scope & $2020-2021$ \\
\hline Source: Own elaboration.
\end{tabular}

Source: Own elaboration.

The conducted empirical studies focused on the identification of (variable) marketing activities of food products among the local community and problems with online sales of products-i.e., (consequently) determination of the role of marketing in shaping the development of this market in Poland. Marketing activities of the surveyed companies was analyzed from the point of view of various criteria:

MA1-additional sales channels;

MA2-number of offered products in e-shops;

MA3 - sources of marketing inspirations;

MA4-applied marketing forms;

MA5- problems in online selling.

The dependent variable was the company's age which represents the company's life cycle, its maturity, experience and competitive potential. The researched relations between the variables were defined in the following hypotheses:

Hypothesis 1 (H1): The age of companies has a positive impact on applied marketing forms;

Hypothesis 2 (H2): The age of companies has a positive impact on sources of marketing inspirations;

Hypothesis 3 (H3): The age of companies has a positive impact on additional sales channels;

Hypothesis 4 (H4): The age of companies has a positive impact on number of products offered;

Hypothesis 5 (H5): The age of companies has a positive impact on problems in online selling.

In order to examine the dependence of individual characteristics of the surveyed entities (operating time of e-shops, number of people supporting the platform) and the above-mentioned variables, the $\chi 2$ statistics was used. The $\chi 2$ test is used for measurement on a nominal scale [101]. However, in order to examine the strength of correlation, the V-Cramer coefficient was used. It measures the strength of the relation between variables, the measurement of which are expressed on a nominal scale [102] (p. 103). The value of the V-Cramer coefficient varies from 0 to 1 . The closer this value to 0 the smaller the strength of the relation between the examined features. The closer this value to 1 the greater the strength of the examined relation. In social sciences, the Cramer's V value between 0 and 0.25 is often considered to indicate a weak association, a value between 0.25 and 0.35 - a medium association and a value above 0.35 - a strong association [103] (p. 12). The correlation above 0.5 sometimes proves a strong relationship between the examined variables. The Statistica 13.1 software (StatSoft, Tulsa, OK, USA) was used for statistical analysis. 


\section{Results and Discussion}

The general characteristics of enterprises that took part in the study are presented in Table 2. The identified factors include the period of the store's existence on the market (market experience), the number of persons supporting the trading platform and the number of products offered in the e-store.

Table 2. Characteristics of companies.

\begin{tabular}{ccc}
\hline Operating Time of the E-Store & Number of Enterprises (n) & $\%$ \\
\hline Shorter than 1 year & 8 & $15.2 \%$ \\
From 1 to 2 years & 7 & $13.2 \%$ \\
From 2 to 5 years & 4 & $7.5 \%$ \\
From 5 to 10 years & 15 & $28.3 \%$ \\
From 10 to 20 years & 19 & $35.8 \%$ \\
\hline Number of people serving the e-store & Number of Enterprises (n) & $\%$ \\
2 & 9 & $17.0 \%$ \\
3 & 20 & $37.7 \%$ \\
4 & 11 & $20.8 \%$ \\
More than 4 persons & 5 & $9.4 \%$ \\
Up to 100 & 8 & $15.1 \%$ \\
From 100 to 500 & 17 & $\%$ \\
From 500 to 1000 & 11 & $32.1 \%$ \\
Over 1000 up to 5000 & 7 & $20.8 \%$ \\
Over 5000 up to 10,000 & 8 & $13.2 \%$ \\
\hline
\end{tabular}

Source: Own elaboration.

The significance of the first element (adopted in the form of a period of online sales) is connected with the market experience. The life cycle of the enterprise and the speed of changes in individual phases depend on many elements: industry, social changes, crises, strategies and many other factors. Assuming the classic division of the enterprise's life cycle into four stages: start-up (up to 2 years), growth (from 3 to 9 years), maturity (from 10 to 19 years) and recession (over 19 years) [16] (p. 1170), there was no entity operating for more than 19 years in the examined group of enterprises. Mature enterprises with a sales expansion rate (usually) equal to the growth rate of the national economy belonged to the largest group. The analysis of the research results will be aimed at confirming whether mature entities are more active in the area of marketing activities than companies operating on the food market for a much shorter time.

By analyzing another parameter characterizing the surveyed entities-i.e., the number of persons working in the e-store, it can be indicated that the obtained results are comparable with the results presented in the report concerning the online sales in Poland [104] (p. 9).

On the other hand, the characteristics of respondents in terms of the number of offered products indicate a large variety of analyzed entities. Some companies offer only their key products, while other companies try to sell not only their own products, but also products manufactured by other producers.

The first area of the study was additional sales channel used by individual entities (Table 3). The combination of the traditional form of sales with e-commerce was used by slightly more than half of the analyzed enterprises ( 27 enterprises- $50.9 \%$ ). It should be emphasized that almost all enterprises $(64.2 \%)$ operating on the market for less than 10 years, and all enterprises operating up to 5 years, were selling products in a traditional way in local shops. Mature companies differ from newly established companies in the distribution strategy, because they are more eager to use other forms such as: Internet auctions, mail order and wholesale. During the analysis of the correlation between the applied forms of sales and the enterprise's age, no statistical relationship was found 
$(p=0.36>0.05)$, hypothesis $3(\mathrm{H} 3)$ was not supported. The most popular sales channels include: internet auctions, traditional / stationary points of sale and wholesale. Similar results, although more diversified, were obtained in previous studies [26] (p. 7), where online stores were much more likely to sell on auction portals.

Table 3. The use of additional sales channels depending on the age of the company.

\begin{tabular}{ccccc}
\hline Company Age & $\begin{array}{c}\text { Internet } \\
\text { Auctions }\end{array}$ & Mail Order & $\begin{array}{c}\text { Traditional } \\
\text { Sales Points }\end{array}$ & Wholesale \\
\hline Shorter than 1 year & 6 & 1 & 4 & 2 \\
From 1 to 2 years & 2 & 0 & 3 & 2 \\
From 2 to 5 years & 2 & 0 & 2 & 3 \\
From 5 to 10 years & 9 & 1 & 8 & 11 \\
From 10 to 20 years & 13 & 10 & 27 & 9 \\
\hline Total & 32 & 12 & 27 \\
\hline Statistical test & \multicolumn{5}{c}{ Significance level $=0.05, \chi 2=13.07, p=0.36$} \\
\hline
\end{tabular}

Another examined issue was the correlation between the number of offered products and the enterprise's age. The value of the $\chi 2$ test's test statistics is 49.51 and its $p$ value $=0.00026$ (Table 4$)$. The obtained result presents the existence of a statistical dependence between the age of the company and the number of products offered in e-commerce in the studied population. The V-Cramer correlation coefficient with a value of 0.48 shows that the strength of the relationship between the examined features is average. It can be observed that the number of offered products increases along with the increasing age of the enterprise; thus, hypothesis 4 (H4) was supported. The age of companies has a positive impact on number of products offered. In the first phase of the life cycle, companies (in the online sales channel) offer a narrow range of products and they treat it as complementary range. Only after the optimal time and the implementation of an adequate strategy and additional resources, more active e-commerce solutions are introduced. As a consequence, this leads to the possibility and willingness to increase the number of sold products. The advantage for clients related to a wide range of products is the ability to make purchases in one store-without the need to visit other e-shops. This reduces the time needed to purchase products and delivery costs. Among the examined companies, five entities offered more than 5000 products. After a deeper analysis, it was found that on these platforms, food products are only an additional assortment and they do not constitute the main sales sector.

Table 4. Correlation between the number of offered products in e-shops and the company's age.

\begin{tabular}{|c|c|c|c|c|c|c|}
\hline Company Age & Up to 100 & $>100$ to 500 & $>500$ to 1000 & $>1000$ to 5000 & $>5000$ to 10,000 & $\begin{array}{c}>10,000 \text { to } \\
50,000\end{array}$ \\
\hline Shorter than 1 year & 5 & 2 & 0 & 1 & 0 & 0 \\
\hline From 1 to 2 years & 6 & 1 & 0 & 0 & 0 & 0 \\
\hline From 2 to 5 years & 3 & 0 & 1 & 0 & 0 & 0 \\
\hline From 5 to 10 years & 3 & 8 & 3 & 0 & 1 & 0 \\
\hline From 10 to 20 years & 3 & 0 & 1 & 8 & 4 & 3 \\
\hline Total & 20 & 11 & 5 & 9 & 5 & 3 \\
\hline
\end{tabular}

When focusing on the analysis of the results of the research concerning marketing activities, the first issue included in the test was the source of the company's inspiration in the context of the applied advertisements. The obtained results, the value of the $\chi 2$ test statistic value and its $p$ value $=0.40$ (Table 5) indicate the lack of a correlation between the examined variables. Hypothesis 2 (H2) has not been confirmed: the age of companies does 
not have a positive impact on sources of marketing inspirations. Nevertheless, after the analysis of the obtained results, it can be noticed that companies operating on the market for less than 5 years mainly use the media as a source of receiving information about effective marketing actions. It could be presumed that the Internet is the most popular choice. It is characterized by large amounts of data and information in the area of marketing forms and tools. Apart from the results of publicly available research (in the form of reports), there are professional information from experts in online webinars and training sessions. An interesting fact is that the analyzed enterprises, only after 10 years from their founding, start to use conferences as a source of information, rather than competition. This can be connected with the acquired extensive experience. By analyzing the data, it can be indicated that companies with at least 5 years of experience more often use information from their clients and employees as an inspiration for further marketing activities than younger companies. The obtained results are also confirmed by other studies, where clients are indicated as the most important source of information [25], and consumer knowledge is of central importance to examining and understanding consumer behavior [105]. Moreover, in Poland, compared to the UK, many more consumers share their information with companies for the purpose of designing advertising campaigns [106].

Table 5. Correlation between sources of marketing inspirations used in e-shops and the age of the company.

\begin{tabular}{cccccc}
\hline Company Age & Customers & Competition & Employees & Conferences & Media \\
\hline Shorter than 1 year & 5 & 3 & 3 & 1 & 1 \\
From 1 to 2 years & 3 & 3 & 1 & 1 & 2 \\
From 2 to 5 years & 4 & 3 & 1 & 2 & 2 \\
From 5 to 10 years & 9 & 8 & 11 & 4 & 2 \\
From 10 to 20 years & 9 & 6 & 11 & 14 & 11 \\
\hline Total & 30 & 23 & 27 & 22 & 18 \\
\hline Statistical test & \multicolumn{5}{l}{}
\end{tabular}

The most popular marketing activities analyzed in other studies were selected for this study $[33,60,107]$. From the point of view of the research objective, the analysis of the marketing forms used by individual enterprises is the most important (Table 6). 12 different forms and methods of marketing were taken into consideration (Z1-Z12):

Z1-Price comparison websites (Ceneo),

Z2-Search engine optimization (SEO),

Z3-pay per click (Google Ads),

Z4-Display marketing (online banners),

Z5-E-mail marketing,

Z6-Public relations actions,

Z7-Loyalty programs,

Z8-Sales promotion (sale, special actions),

Z9-TV commercials,

Z10_-Radio advertisements,

Z11-Advertising in the press,

Z12-Social media marketing (SMM). 
Table 6. Correlation between the applied marketing forms and the age of the company.

\begin{tabular}{ccccccccccccc}
\hline Company Age & Z1 & Z2 & Z3 & Z4 & Z5 & Z6 & Z7 & Z8 & Z9 & Z10 & Z11 & Z12 \\
\hline Shorter than 1 year & 1 & 3 & 4 & 1 & 1 & 0 & 1 & 2 & 0 & 0 & 0 & 4 \\
From 1 to 2 years & 0 & 2 & 3 & 1 & 1 & 3 & 1 & 3 & 0 & 0 & 1 & 4 \\
From 2 to 5 years & 1 & 1 & 2 & 0 & 1 & 2 & 3 & 3 & 0 & 0 & 0 & 4 \\
From 5 to 10 years & 1 & 11 & 10 & 4 & 4 & 7 & 7 & 11 & 1 & 3 & 4 & 12 \\
From 10 to 20 years & 7 & 13 & 9 & 9 & 12 & 11 & 7 & 16 & 3 & 3 & 5 & 13 \\
\hline Total & 10 & 30 & 28 & 15 & 19 & 23 & 19 & 35 & 4 & 6 & 10 & 37 \\
\hline
\end{tabular}

Statistical test

Significance level $=0.05, \chi 2=26.23, p=0.984611$

During the analysis of the correlation between the applied forms of marketing and the enterprise's age, no statistical relationship was found ( $p=0.98>0.05)$, hypothesis 1 (H1) was not supported. Popular marketing forms were selected as dependent variables. The obtained results of the statistical test did not show any correlation between the age of the company and the applied various marketing activities. Nevertheless, it can be noticed that the number of used tools increases with the experience and time of existence of the enterprise. Sales promotion and social media marketing (SMM) were indicated as the most popular forms. The great popularity of social media marketing in the e-commerce sector is also confirmed by other studies $[108,109]$. The results of the Polish e-commerce survey, presented in the InternetStandard report, also confirm that the three most popular marketing activities, similarly to this survey, include SEM activities and sales promotion [26]. Sales promotion (Z8) is one of the most important promotion instruments. It is especially effective in the area of activities conducted by local entrepreneurs. Furthermore, due to the nature of the application, it ensures relatively quick sales results-this is willingly used by companies that do not focus on long-term benefits in their strategies. Sales promotion includes actions and tools such as: samples, coupons, contests, discounts, lotteries, bonuses and gifts. Both sales promotion and social media marketing are used by the majority of examined entities - regardless of the age of the company. Currently, there is a significant increase in the importance of social media in the area of marketing communication. The advantages associated with SMM (Z12) noted by entrepreneurs are a large number of potential clients, relatively low cost of marketing, and the ability to personalize recipients. This is particularly important in the area of local actions, because there is a possibility of demographic selection of marketing recipients, and all popular social networks (Facebook, YouTube, Snapchat) provide the possibility of presenting ads to recipients located in a specific geographical area. An equally popular method was SEO-search engine optimization (Z2), i.e., activities aimed at increasing the position of a website in search engines. The Google Maps tool has a particularly positive impact on local recipients of advertising messages. By placing ads on Google Maps, there is a possibility of attracting the attention of clients from the selected area. Ads in Google Maps help people, who are interested in taking advantage of a local company's offer, to find a right location. A similarly attractive solution is the company's visibility in local search results. It seems to be a necessary condition for any locally targeted business. The smaller the city the greater chance of being competitive.

The next four popular marketing forms received the same number of responses in the test. PPC (Pay Per Click) advertising (Z3) is related to search engine optimization. It is a paid form in the Google search engine. Its main advantage (compared to SEO) is the speed of launch, because the campaign is active immediately after paying the required amount to the account. Advertisements in Google Ads appear on the first page of Google in highly visible places (at the very top or on the right side) and they are practically little difference from organic results. The advantage for local solution is (like in other tools) the possibility of selecting recipients of the advertising message depending on their location. Ads can be directed to selected cities, voivodeships or even to a selected district or any part of the city. Many analyzed enterprises also take advantage of e-mail marketing (Z5). This form is very 
often associated with the negative phenomenon of SPAM-i.e., receiving unwanted and unexpected messages. However, e-mail marketing allows direct contact with clients. It enables to build a long-lasting bond with the recipient and gain loyalty of clients. Thanks to the properly selected databases of recipients, demographic targeting, geolocation targeting and behavioral targeting are possible. In this approach, interests and preferences of the user are also important. Other popular forms of marketing are PR activities (Z6). An interesting fact is that PR was indicated even by enterprises operating on the market for more than 1 year. Public relations actions are necessary at the stage of introducing a new product or rebranding, during the building of awareness and identify of a new brand, and even during a social campaign. PR is connected with taking care of good communication and relations with the environment. The purpose of activities is to develop a good image, trust and understanding. These are particularly important factors in marketing communication with local clients. The last of the four indicated marketing methods are loyalty programs (Z7). This tool is often used during marketing campaigns. It draws attention of client to the product/brand and increases their attachment to the company. One of the factors determining the effectiveness of loyalty programs is the recommendation mechanism, which is particularly important in local communities. A good loyalty program is not only a way to motivate a client to return, but also a method to attract new clients.

Price comparison websites, TV commercials, radio advertisements and advertising in the press belong to the marketing group which is used by the smallest number of examined enterprises. While advertising in popular media is relatively expensive and has justification for use in national actions, it is not used in the case of local sellers in the food sector. On the other hand, price comparison websites (Z1) seem to be a proper marketing tool, because tools and mechanisms aimed at supporting food producers selling online among the local community have been implemented. By comparing the results to other reports [26,104], we can see differences in the popularity of price comparison websites as a marketing tool. Overall, price comparators are one of the most frequently used e-commerce marketing activities in Poland, but in this study it is not a very popular marketing instrument. This difference may result from the fact that the analyzed area were food producers. The likely reason for the low attractiveness of this tool for the analyzed enterprises is the necessity to sell products at low prices. Furthermore, the food industry is characterized by relatively low online sales.

Each of the described marketing tools and forms (used by companies) is characterized by a large diversification of possibilities and advantages. The research was declarative and concerned only the indication of applied marketing forms and tools. Therefore, an in-depth study concerning details, targets and involvement of the company in various marketing forms should be conducted. In connection with the above, the next question was the issue connected with the problems in the area of online sales (Table 7).

The obtained results, the value of the $\chi 2$ test statistics and its $p$ value $=0.90$ (Table 7) indicate the lack a correlation between the examined variables, thus hypothesis 5 (H5) was not supported. The above table presents that the number of indicated problems increases with the company's age. Among the analyzed enterprises operating in the e-commerce industry for up to 5 years, the main problems identified were: the area related to the economic situation and IT infrastructure. It should be mentioned that the study concerned 2019, when the impact of the COVID-19 phenomenon could not be included in the answers of respondents. Among the companies that have been operating on the market for the longest time (over 10 years), there is much greater number of problematic areas. Apart from the economic situation, the fiscal and legal scopes are also particularly problematic, which is also confirmed by other publications $[43,55]$. Economic activity conducted in the form of e-commerce is generally covered by the same legal and tax regulations as traditional sales with some exceptions. Exceptions and differences in their interpretation are very often large problems for entrepreneurs, especially for small entities that do not have appropriate legal and tax support. For example, mail order sales are taxed in Poland in accordance with the Polish VAT rates (provided that it does not exceed the specified limit). This limit is 
set by each EU country at a different level and ranges from 35,000 EUR (in the majority of EU countries) to 100,000 EUR in Germany and France. Moreover, problems relate to the form of documenting online sales, details concerning the acceptance of complaints and other obligations of the e-seller. Furthermore, in the survey, several enterprises indicated cooperation with courier companies and the area of IT infrastructure as problematic matters. The logistics industry has become a beneficiary of the dynamically developing e-commerce. E-shops that have been operating for less than 3 years usually use standard forms of delivery such as courier or postal delivery. More advanced solutions, such as parcel dispensing machines and own delivery, are sometimes implemented. However, in the area of food products and the local range of operation, the most important form seems to be the possibility of personal pickup or fast delivery. The most convenient method for the delivery of orders is home delivery. This service is usually offered by large enterprises such as Carrefour or Frisco. On the other hand, the fewest problems were identified in logistic services, cooperation with suppliers, marketing and payment processing companies.

Table 7. Correlation between problems encountered while online selling and the age of the company.

\begin{tabular}{|c|c|c|c|c|c|c|c|c|c|}
\hline Company Age & $\begin{array}{l}\text { Customer } \\
\text { Service }\end{array}$ & Suppliers & $\begin{array}{l}\text { Logistic } \\
\text { Service }\end{array}$ & Couriers & $\begin{array}{l}\text { Payment } \\
\text { Processing } \\
\text { Companies }\end{array}$ & $\begin{array}{l}\text { IT InfraS- } \\
\text { tructure }\end{array}$ & $\begin{array}{l}\text { Economic } \\
\text { Situation }\end{array}$ & $\begin{array}{l}\text { Fiscal and } \\
\text { Legal } \\
\text { MatTers }\end{array}$ & Marketing \\
\hline Shorter than 1 year & 2 & 1 & 0 & 2 & 1 & 3 & 5 & 1 & 2 \\
\hline From 1 to 2 years & 2 & 0 & 1 & 1 & 1 & 3 & 3 & 2 & 1 \\
\hline From 2 to 5 years & 1 & 0 & 0 & 0 & 0 & 1 & 3 & 0 & 0 \\
\hline From 5 to 10 years & 3 & 1 & 1 & 6 & 3 & 4 & 6 & 3 & 1 \\
\hline From 10 to 20 years & 3 & 4 & 3 & 2 & 2 & 3 & 11 & 10 & 3 \\
\hline Total & 11 & 6 & 5 & 11 & 7 & 14 & 28 & 16 & 7 \\
\hline \multicolumn{2}{|c|}{ Statistical test } & \multicolumn{8}{|c|}{ Significance level $=0.05, \chi^{2}=22.35, p=0.90$} \\
\hline
\end{tabular}

\section{Conclusions}

The main purpose of this study was to identify of the correlation of the analyzed variables with the age of companies and identification the most popular marketing forms by the analyzed enterprises, which were food producers selling online among the local community. The size of the e-commerce market in Poland is growing in a dynamic way. The expansion of e-commerce has made the online shipping market an essential part of the total sales market in recent years. The food industry in Poland is characterized by a steady increase in value. This is one of the sectors that quickly recovered after the crisis connected with the political transformation in Poland. Online sale of food products is growing dynamically - annual average: approx. $15 \%$. However, food is still the segment of the least purchased products on the Internet. The obtained results and their analysis enable to conclude that there is a strong relationship between the number of offered products in eshops and the company's age. By analyzing the data from the table, it can be concluded that the correlation is positive, and the number of products on offer increases with the age of the company. As mentioned in other studies [38], increasing the merchandise assortment of an e-shop does not always have a positive effect on increasing sales. A valuable activity is the use of filtration and offer personalization mechanisms on the trading platform in order to reduce the number of products presented. Therefore, an additional study should be carried out to identify activities and their effectiveness in the area of the number of products. The analyzed enterprises most often use sales promotion, positioning of websites and social media marketing. The first mentioned instrument is a classic element of promotion and it is based mainly on such actions and tools as: samples of products, discount coupons, contests, discounts, lotteries and gifts. However, in the case of local SEO search results, there are two concepts for the regionalization of keywords. It is also possible to advertise products in a selected area in social media. This enables to increase the effectiveness of marketing actions. A bare profile in social media is insufficient to increase sales. Currently, the creation of effective content and the use of video materials, and in the case of food products also photos, are the adequate marketing activities. On the other hand, during the designing of promotional campaigns among local recipients, an additional element is the 
creation of a community around social media channels. The obtained results, indicating the high popularity of social media activities in the food industry, were also confirmed in other studies [110] (p. 15) [111]. Food belongs to the group of products characterized by high consumer ethnocentrism. Ethnocentrism means the preference for local products, as well as emphasizing their positive features [112], [113] (p. 2). Along with the development of the food economy in Poland and taking into account the increased interest in online shopping, due to the COVID-19 pandemic, the consumer ethnocentrism will (likely) play an increasingly important role. The conscious use of this trend is important to ensure the success of not only government policies, but also local producers selling online in a competitive food product environment. The obtained results, especially in comparison with the previous literature, provide more detailed information. In addition, the high popularity of SEO activity is also confirmed by other studies among SME [114-116], that SEO have substantial positive impacts on number of user visits to SME websites, average duration of user visits, as well as the company's overall sales revenues.

Opportunities and a variety of forms of marketing are an important resource of competitive advantage for SMEs [117] (p. 658). This paper complements the literature by identifying the marketing forms used by local food producers and online retailers. The obtained results and the conducted analysis suggest the existence of a relationship between the age of the company: and the problems encountered when conducting online sales, and between the sources of marketing inspiration used in the e-shop.

The academic implications of this study are as follows. First, this study suggests there are four popular marketing activities. This finding can provide a basis for further development in related theories. Secondly, the results of the study do not confirm the relationship between the age of the companies and the number of tools and marketing activities used. Also important is the lack of similar previous research on food producers selling products locally. This paper enriches existing academic literature and will help future studies.

Moreover, given the lack of research on the relationship between the age of companies and the marketing activities of food producers, the mechanism of interaction between them is valuable information. The results of this study enrich researchers' knowledge, revealing the mechanism of the influence of the age of the enterprise with selected elements of marketing activities.

The practical implications of this study are as follows. First, the obtained results and their analysis can be used by similar companies for planning marketing activities and for the use of decision-making processes in business practice. Thus, marketing managers should operate in the area of search engine marketing (SEO and PPC), sales promotion and social media marketing, especially among young companies. Second, customers and employees of companies have been indicated as the most popular sources of information regarding their marketing activities. Therefore, the electronic market of food producers should improve methods and tools supporting obtaining information from indicated groups. These activities will help them survive in turbulent market environments, especially among companies selling products locally.

Another useful approach is to use company age, which might affect the various independent variables simultaneously. Companies experiences different stages in the life cycle, such as entrepreneurship, growth, maturity, and recession. Enterprises at different stages will have different characteristics, experiences and various risks. Our findings only partially support this proposal.

The current study had several research and methodological limitations. In terms of methodological limitations, the study was conducted on a small and selected sample. The sample size is too small, therefore the obtained relationships and correlations based on the obtained data may not provide a representative and reliable result. Moreover, the research was conducted on Polish companies, therefore the use of analysis, recommendations and conclusions should be useful for Polish companies. However, when considering the possibility of expansion of companies to foreign markets, it is possible to use the presented 
data by foreign companies introducing their products to the Polish market. Imports and exports of food have remained stable even through recessions and crises (food being a necessity good). Polish food producers are more and more often encountering competition on the part of transnational corporations [118] (p. 66).

The considerations presented above on the scope of the use of the marketing forms among food producers in Poland do not exhaust the discussed issues. Due to the small sample size and the declarative nature of the survey, deeper research should be conducted, for the confirmation of the obtained results. Further research should broaden the scope in order to obtain information about more details regarding promotional activities. In the context of the most popular forms of marketing identified as: SEO, SMM and sales promotion, information concerning the effectiveness, scope and costs of marketing measures, should be obtained. The variety of social media diversifies their use [119] (p. 982), therefore further research should also focus on identifying the dependence of marketing goals with the selection of specific social networks as a channel of marketing communication with customers. These results would enable the development of a model of marketing activities of the analyzed enterprises. Today, the COVID-19 pandemic has contributed, among others, to the expansion of the market, especially the online sales of food products with a small scale of operation. Therefore, the obtained results should be repeated in order to receive information about contemporary changes in marketing activities of companies selling food products online among the local community.

Funding: This research received no external funding.

Institutional Review Board Statement: Not applicable.

Informed Consent Statement: Not applicable.

Data Availability Statement: The data presented in this study are available on request from the corresponding author.

Conflicts of Interest: The author declares no conflict of interest.

\section{References}

1. GUS: Produkcja Wyrobów Przemysłowych w 2019 Roku. Available online: https://stat.gov.pl/download/gfx/portalinformacyjny/ pl/defaultaktualnosci/5477/8/3/1/produkcja_wyrobow_przemyslowych_w_2019_r.pdf (accessed on 21 October 2020).

2. Zakrzewska, A.; Chojnacki, P. Innovation and efficiency of food industry firms in Poland by Regions. Pr. Nauk. Uniw. Ekon. Wrocławiu 2020, 64, 142-153. [CrossRef]

3. Klewitz, J.; Hansen, E.G. Sustainability-oriented innovation of SMEs: A systematic review. J. Clean. Prod. 2014, 65, 57-75. [CrossRef]

4. León-Bravo, V.; Moretto, A.; Cagliano, R.; Caniato, F. Innovation for sustainable development in the food industry: Retro and forward-looking innovation approaches to improve quality and healthiness. Corp. Soc. Responsib. Environ. Manag. 2019, 26, 1049-1062. [CrossRef]

5. Le Bars, A.; Mangematin, V.; Nesta, L. Innovation in SME's: The Missing Link. Proceedings of the High-Technology Small Firms. In Proceedings of the 6th Annual International Conference, Enschede, The Netherlands, 4-5 June 1998; Volume 1, pp. 307-324.

6. Caiazza, R.; Volpe, T.; Stanton, J.L. Innovation in Agro-Foods: A Comparative Analysis of Value Chains. J. Int. Food Agribus. Mark. 2016, 28, 1-14. [CrossRef]

7. Gunes, G.; Tekin, M.D. Consumer awareness and acceptance of irradiated foods: Results of a survey conducted on Turkish consumers. LWT 2006, 39, 444-448. [CrossRef]

8. Lindsey, P.J.; Martin, M.V.; Nuckton, C.F. Strategic Marketing and the Dynamics of Food Consumption. J. Int. Food Agribus. Mark. 1993, 4, 44-55. [CrossRef]

9. McLean, G.; Al-Nabhani, K.; Wilson, A. Developing a Mobile Applications Customer Experience Model (MACE)—Implications for Retailers. J. Bus. Res. 2018, 85, 325-336. [CrossRef]

10. Dora, M.; Wesana, J.; Gellynck, X.; Seth, N.; Dey, B.; De Steur, H. Importance of sustainable operations in food loss: Evidence from the Belgian food processing industry. Ann. Oper. Res. 2019, 290, 47-72. [CrossRef]

11. Trojanowski, T. Sustainable management of production activities in polish enterprises of the food industry. Manag. Theory Stud. Rural. Bus. Infrastruct. Dev. 2020, 41, 80-88. [CrossRef]

12. Ahumada, O.; Villalobos, J.R. Application of planning models in the agri-food supply chain: A review. Eur. J. Oper. Res. 2009, 196, 1-20. [CrossRef] 
13. Czajkowski, T.; Szymanski, G. Analysis of the ROPO Effect amongst Men in the Clothing Industry in Poland. Fibres Text. East. Eur. 2020, 28, 8-11. [CrossRef]

14. Braja, M.; Sawicka, J. Competitive advantages of polish food producers on the europen union market in the post-accession period. Acta Sci. Pol. Oeconomia 2017, 16, 13-22. [CrossRef]

15. Fan, S.; Wang, C. Firm age, ultimate ownership, and R\&D investments. Int. Rev. Econ. Financ. 2019. [CrossRef]

16. Lu, X.; Wang, J. A Review of the Classification of Enterprise Life Cycle. Mod. Econ. 2018, 9, 1169-1178. [CrossRef]

17. Bakarich, K.M.; Hossain, M.; Weintrop, J. Different time, different tone: Company life cycle. J. Contemp. Account. Econ. 2018, 15, 69-86. [CrossRef]

18. Alqahtani, J.; Duong, L.; Taylor, G.; Eulaiwi, B. Outside directors, firm life cycle, corporate financial decisions and firm performance. Emerg. Mark. Rev. 2021, 100820. [CrossRef]

19. Quinn, R.E.; Cameron, K. Organizational Life Cycle and Shifting, Criteria of Effectiveness, Some Preliminary Evidence. Manag. Sci. 1983, 29, 33-51. [CrossRef]

20. Abd Aziz, N.N.; Samad, S. Innovation and Competitive Advantage: Moderating Effects of Firm Age in Foods Manufacturing SMEs in Malaysia. Procedia Econ. Financ. 2016, 35, 256-266. [CrossRef]

21. Wee, T.T.; Ahmed, Z.U. Managing Market Intelligence: An Asian Marketing Research Perspective. Mark. Intell. Plan. 1999, 17, 298-306.

22. Wilson, R.D.; Blankenship, A.B.; Breen, G.E. State of the Art Marketing Research. J. Mark. Res. 1994, 31, 575. [CrossRef]

23. Baruk, A.I. Co-creation of a food marketing offer by final purchasers in the context of their lifestyles. Br. Food J. 2020, 123, 1494-1512. [CrossRef]

24. Singh, A.K.; Sailo, M. Consumer Behavior in Online Shopping: A Study of Aizawl. Int. J. Bus. Manag. Res. 2013, 1, 45-49.

25. Molinillo, S.; Anaya-Sánchez, R.; Liébana-Cabanillas, F. Analyzing the effect of social support and community factors on customer engagement and its impact on loyalty behaviors toward social commerce websites. Comput. Hum. Behav. 2019, 108, 105980. [CrossRef]

26. InternetStandard Raport Ecommerce Standard 2014. Available online: https://www.internetstandard.pl/whitepaper/2591 -ecommerceSTANDARD-2014.html (accessed on 20 July 2021).

27. Fernández-Uclés, D.; Bernal, E.; Mozas-Moral, A.; Medina-Viruel, M.J. The importance of websites for organic agri-food producers. Econ. Res. 2019, 33, 2867-2880. [CrossRef]

28. Russo, C.; Simeone, M.; Perito, M.A. Educated Millennials and Credence Attributes of Food Products with Genetically Modified Organisms: Knowledge, Trust and Social Media. Sustainability 2020, 12, 8534. [CrossRef]

29. Molla, A.; Licker, P.S. E-commerce systems success: An attempt to extend and specify the Delone and Maclean model of is success. J. Electron. Commer. Res. 2011, 2, 131-141.

30. Cheng, S.; Cheng, B.L.; Lee, H.S. A Study of E-Shopping Intention in Malaysia: The Influence Of Generation X \& Y. Aust. J. Basic Appl. Sci. 2012, 6, 28-35.

31. Amir, N.; Choon, L.K.; Farshad, M. Evaluating the impacts of customer experience on purchase intention. Int. J. Bus. Manag. 2013, 8, 128-145.

32. Beatrice, C.B.; Kambona, O.O.; Fredrick, O.A. Mediational role of customer emotions in the relationship between customer experience and purchase behavior in the hotel industry. J. Market. Consum. Res. 2019, 58, 43-50.

33. Florio, A.M.; Feillet, D.; Hartl, R.F. The delivery problem: Optimizing hit rates in e-commerce deliveries. Transp. Res. 2018, 117, 455-472. [CrossRef]

34. Damanpour, F.; Damanpour, J.A. E-business E-commerce evolution: Perspective and strategy. Financ. Manag. 2001, 27, 16-33. [CrossRef]

35. Chang, C. The Effect of the Number of Product Subcategories on Perceived Variety and Shopping Experience in an Online Store. J. Interact. Mark. 2011, 25, 159-168. [CrossRef]

36. Lancaster, K. The Economics of Product Variety: A Survey. Mark. Sci. 1990, 9, 189-206. [CrossRef]

37. Kahn, B.E. Dynamic Relationships with Customers: High-Variety Strategies. J. Acad. Mark. Sci. 1998, 26, 45-53. [CrossRef]

38. Kurien, R.; Paila, A.R.; Nagendra, A. Application of Paralysis Analysis Syndrome in Customer Decision Making. Procedia Econ. Financ. 2014, 11, 323-334. [CrossRef]

39. Fasolo, B.; Hertwig, R.; Huber, M.; Ludwig, M. Size, Entropy, and Density: What Is the Difference that Makes the Difference Between Small and Large Real-World Assortments? Psychol. Mark. 2009, 26, 254-279. [CrossRef]

40. Iyengar, S.S.; Lepper, M.R. When Choice Is Demotivating: Can One De-sire Too Much of a Good Thing? J. Personal. Soc. Psychol. 2000, 79, 995-1006. [CrossRef]

41. Scheibe, A. Factors determining the impact of informal information disseminated via the Internet on purchasing decisions. Manag. Financ. 2012, 4, 230-232.

42. Reddy, N.A.; Divekar, B.R. A Study of Challenges Faced By E-commerce Companies in India and Methods Employed to Overcome Them. Procedia Econ. Financ. 2014, 11, 553-560. [CrossRef]

43. Polański, P.P. Revisiting country of origin principle: Challenges related to regulating e-commerce in the European Union. Comput. Law Secur. Rev. 2018, 34, 562-581. [CrossRef]

44. Tigre, P.B.; Dedrick, J. E-commerce in Brazil: Local adaptation of a global technology. Electron. Mark. 2004, 14, 36-47. [CrossRef]

45. Haji, K. E-commerce development in rural and remote areas of BRICS countries. J. Integr. Agric. 2021, 20, 979-997. [CrossRef] 
46. Yapar, B.K.; Bayrakdar, S.; Yapar, M. The Role of Taxation Problems on the Development of E-Commerce. Procedia Soc. Behav. Sci. 2015, 195, 642-648. [CrossRef]

47. Tran, L.T.T. Managing the effectiveness of e-commerce platforms in a pandemic. J. Retail. Consum. Serv. 2020, 58, 102287. [CrossRef]

48. Almousa, M. Barriers to E-Commerce Adoption: Consumers' Perspectives from a Developing Country. iBusiness 2013, 5, 65-71. [CrossRef]

49. Kshetri, N. Barriers to e-commerce and competitive business models in developing countries: A case study. Electron. Commer. Res. Appl. 2007, 6, 443-452. [CrossRef]

50. Oncini, F.; Bozzini, E.; Forno, F.; Magnani, N. Towards food platforms? An analysis of online food provisioning services in Italy. Geoforum 2020, 114, 172-180. [CrossRef]

51. Cristobal-Fransi, E.; Martin-Fuentes, E.; Ramon, N.D. Behavioural analysis of subjects interacting with information technology: Categorising the behaviour of e-consumers. Int. J. Serv. Technol. Manag. 2015, 21, 163. [CrossRef]

52. Lin, Y.-K.; Yeh, C.-T.; Huang, C.-F. Reliability evaluation of a stochastic-flow distribution network with delivery spoilage. Comput. Ind. Eng. 2013, 66, 352-359. [CrossRef]

53. Lemos, J.; Garcia, M.V.; Mello, R.D.O.; Copetti, M.V. Consumers complaints about moldy foods in a Brazilian website. Food Control 2018, 92, 380-385. [CrossRef]

54. Hsu, C.-I.; Hung, S.-F.; Li, H.-C. Vehicle routing problem with time-windows for perishable food delivery. J. Food Eng. 2007, 80, 465-475. [CrossRef]

55. Keshri, A.K.; Mishra, B.K.; Rukhaiyar, B.P. When rumors create chaos in e-commerce. Chaos Solitons Fractals 2019, $131,109497$. [CrossRef]

56. Gao, X.; Shi, X.; Guo, H.; Liu, Y. To buy or not buy food online: The impact of the COVID-19 epidemic on the adoption of e-commerce in China. PLoS ONE 2020, 15, e0237900. [CrossRef]

57. Gee, I.M.; Heard, B.R.; Webber, M.E.; Miller, S.A. The Future of Food: Environmental Lessons from E-Commerce. Environ. Sci. Technol. 2020, 54, 14776-14784. [CrossRef]

58. Magana, G. Online Grocery Shopping Report 2020: Market Stats and Delivery Trends for Ecommerce Groceries. Available online: https:/ / www.businessinsider.com/online-grocery-report?IR=T (accessed on 27 November 2020).

59. Walecka, A. The Role of Relational Capital in Anti-Crisis Measures Undertaken by Companies-Conclusions from a Case Study. Sustainability 2021, 13, 780. [CrossRef]

60. Gemius: E-commerce w Polsce Gemius dla e-Commerce Polska. Available online: https://www.gemius.pl/wszystkie-artykulyaktualnosci/e-commerce-w-polsce-2020.html (accessed on 21 June 2021).

61. Darby, K.; Batte, M.T.; Ernst, S.; Roe, B. Decomposing Local: A Conjoint Analysis of Locally Produced Foods. Am. J. Agric. Econ. 2008, 90, 476-486. [CrossRef]

62. Ozturk, S.B.; Akoglu, A. Assessment of local food use in the context of sustainable food: A research in food and beverage enterprises in Izmir, Turkey. Int. J. Gastron. Food Sci. 2020, 20, 100194. [CrossRef]

63. Schrager, B. Local food beyond fixed scales and values: The scalar politics of Japan's jidori chicken mosaics. J. Rural. Stud. 2020, 81, 116-126. [CrossRef]

64. Fonte, M. Knowledge, food and place. A way of producing, a way of knowing. Sociol. Rural 2008, 48, 200-222. [CrossRef]

65. Story, M.; French, S. Food Advertising and Marketing Directed at Children and Adolescents in the US. Int. J. Behav. Nutr. Phys. Act. 2004, 1, 3. [CrossRef]

66. Wicks, J.L.; Warren, R.; Fosu, I.; Wicks, R.H. Dual-Modality Disclaimers, Emotional Appeals, and Production Techniques in Food Advertising Airing During Programs Rated for Children. J. Advert. 2009, 38, 93-105. [CrossRef]

67. Atkin, C.; Heald, G. The Content of Children's Toy and Food Commercials. J. Commun. 1977, 27, 107-114. [CrossRef]

68. Ashley, C.; Tuten, T.L. Creative Strategies in Social Media Marketing: An Exploratory Study of Branded Social Content and Consumer Engagement. Psychol. Mark. 2014, 32, 15-27. [CrossRef]

69. Du Plessis, C. The role of content marketing in social media content communities. S. Afr. J. Inf. Manag. 2017, 19. [CrossRef]

70. Agichtein, E.; Castillo, C.; Debora, D.; Gionis, A. Finding high-quality content in social media. In Proceedings of the 2008 International Conference on Web Search and Data, Palo Alto, CA, USA, 11-12 February 2008; pp. 183-194.

71. You, J.-J.; Jong, D.; Wiangin, U. Consumers' Purchase Intention of Organic Food via Social Media: The Perspectives of TaskTechnology Fit and Post-acceptance Model. Front. Psychol. 2020, 11, 579274. [CrossRef] [PubMed]

72. González-Díaz, C.; Vilaplana-Aparicio, M.; Iglesias-García, M. How Is Functional Food Advertising Understood? An Approximation in University Students. Nutrients 2020, 12, 3312. [CrossRef]

73. Simeone, M.; Scarpato, D. Sustainable consumption: How does social media affect food choices? J. Clean. Prod. 2020, $277,124036$. [CrossRef]

74. Kim, D.H.; Jang, S.C. Ethnic food advertising formats and consumers' responses: Picture-dominant or text-dominant? Int. J. Hosp. Manag. 2019, 82, 5-12. [CrossRef]

75. Vega, M.; Torres, F.J.; Murgado, E.M.; Parras, M. Organic as a heuristic cue: What Spanish consumers mean by organic foods. Psychol. Mark. 2014, 31, 349-359. [CrossRef]

76. McComas, K.A.; Besley, J.; Steinhardt, J. Factors influencing U.S. consumer support for genetic modification to prevent crop disease. Appetite 2014, 78, 8-14. [CrossRef] 
77. Lewis, M.; Hill, A. Food advertising on British children's television: A content analysis and experimental study with nine-year olds. Int. J. Obes. 1998, 22, 206-214. [CrossRef] [PubMed]

78. Smithers, L.G.; Wang, X.; Haag, D.; Agnew, B.; Lynch, J.; Sorell, M. Discretionary food advertising on television in 2017: A descriptive study. Aust. N. Zeal. J. Public Health 2019, 43, 519-521. [CrossRef] [PubMed]

79. León-Flández, K.; Royo-Bordonada, M.; Moya-Geromini, M.; Bosqued-Estefanía, M.J.; López-Jurado, L.; Damián, J. Marketing techniques in television advertisements of food and drinks directed at children in Spain. Int. J. Public Health 2018, 63, 733-742. [CrossRef] [PubMed]

80. Smithers, L.G.; Haag, D.G.; Agnew, B.; Lynch, J.; Sorell, M. Food advertising on Australian television: Frequency, duration and monthly pattern of advertising from a commercial network (four channels) for the entire. J. Paediatr. Child Health 2018, 54, 962-967. [CrossRef] [PubMed]

81. Boyland, E.J.; Burgon, R.H.; Hardman, C.A. Reactivity to television food commercials in overweight and lean adults: Physiological, cognitive and behavioural responses. Physiol. Behav. 2017, 177, 182-188. [CrossRef]

82. Santana, M.O.; Guimarães, J.S.; Leite, F.H.M.; Mais, L.A.; Horta, P.M.; Martins, A.P.B.; Claro, R.M. Analysing persuasive marketing of ultra-processed foods on Brazilian television. Int. J. Public Health 2020, 65, 1-11. [CrossRef]

83. Carins, J.E.; Rundle-Thiele, S.R. Eating for the better: A social marketing review (2000-2012). Public Health Nutr. 2014, 17, 1628-1639. [CrossRef]

84. Harris, J.L.; Brownell, K.D.; Bargh, J.A. The Food Marketing Defense Model: Integrating Psychological Research to Protect Youth and Inform Public Policy. Soc. Issues Policy Rev. 2009, 3, 211-271. [CrossRef]

85. Bragg, M.A.; Roberto, C.A.; Harris, J.L.; Brownell, K.D.; Elbel, B. Marketing Food and Beverages to Youth Through Sports. J. Adolesc. Health 2017, 62, 5-13. [CrossRef]

86. Harris, J.L.; Schwartz, M.B.; Munsell, C.R. Fast food FACTS: Measuring Progress in Nutrition and Marketing to Children and Teens; Yale Rudd Center for Food Policy and Obesity: New Haven, CT, USA, 2013.

87. Gunter, B. What is the Balance of Evidence for the Effects of Food. In Food Advertising; Palgrave Macmillan: Leicester, UK, 2016; pp. 37-75. [CrossRef]

88. Boyland, E.J.; Nolan, S.N.; Kelly, B.; Tudur-Smith, C.; Jones, A.; Halford, J.C.; Robinson, E. Advertising as a cue to consume: A systematic review and meta-analysis of the effects of acute exposure to unhealthy food and nonalcoholic beverage advertising on intake in children and adults. Am. J. Clin. Nutr. 2016, 103, 519-533. [CrossRef]

89. Pettigrew, S.; Roberts, M.; Chapman, K.; Quester, P.; Miller, C. The use of negative themes in television food advertising. Appetite 2012, 58, 496-503. [CrossRef] [PubMed]

90. Hinsch, C.; Felix, R.; Rauschnabel, P.A. Nostalgia beats the wow-effect: Inspiration, awe and meaningful associations in augmented reality marketing. J. Retail. Consum. Serv. 2019, 53, 101987. [CrossRef]

91. Begley, T.M. Using founder status, age of firm, and company growth rate as the basis for distinguishing entrepreneurs from managers of smaller businesses. J. Bus. Ventur. 1995, 10, 249-263. [CrossRef]

92. McMillan, G.S.; Thomas, P. Financial success in biotechnology: Company age versus company science. Technovation 2005, 25, 463-468. [CrossRef]

93. Liu, H.; Zhang, Q. Firm age and realized idiosyncratic return volatility in China: The role of short-sales constraints. Int. Rev. Financ. Anal. 2021, 75, 101745. [CrossRef]

94. Polasik, M.; Huterska, A.; Iftikhar, R.; Mikula, S. The impact of Payment Services Directive 2 on the PayTech sector development in Europe. J. Econ. Behav. Organ. 2020, 178. [CrossRef]

95. Patil, H.; Divekar, B.R. Inventory Management Challenges for B2C E-commerce Retailers. Procedia Econ. Finance 2014, 11, 561-571. [CrossRef]

96. Stanisławski, R. Open Innovation as a Value Chain for Small and Medium-Sized Enterprises: Determinants of the Use of Open Innovation. Sustainability 2020, 12, 3290. [CrossRef]

97. Sobocińska, M.; Mazurek-Łopacińska, K.; Skowron, S.; Graczyk, A.; Kociszewski, K. The Role of Marketing in Shaping the Development of the Market of Organic Farming Products in Poland. Sustainability 2020, 13, 130. [CrossRef]

98. Leavy, P. Research Design: Quantitative, Qualitative, Mixed Methods, Arts-Based, and Community-Based Participatory Research Approaches; The Guilford Press: New York, NY, USA, 2017.

99. Cash, P. Where next for design research? Understanding research impact and theory building. Des. Stud. 2020, 68, 113-141. [CrossRef]

100. Colquitt, J.A.; Zapata-Phelan, C.P. Trends in Theory Building and Theory Testing: A Five-Decade Study of the Academy of Management Journal. Acad. Manag. J. 2007, 50, 1281-1303. [CrossRef]

101. Cochran, W.G. The chi-square goodness-of-fit test. Ann. Math. Stat. 1952, 23, 315-345. [CrossRef]

102. Babu, S.C.; Sanyal, P. Food Security, Poverty and Nutrition Policy Analysis; Academic Press: Cambridge, MA, USA, 2009. [CrossRef]

103. de Waal, T. Statistical matching: Experimental results and future research questions. Stat. Neth. 2015, 11, 129-136. [CrossRef]

104. InternetStandard. Raport 2016 Ecommerce Standard. Available online: https://www.internetstandard.pl/whitepaper/2842-Ecommerce-Standard-2016.html (accessed on 2 February 2021).

105. Coulter, R.A.; Price, L.L.; Feick, L.; Micu, C. The Evolution of Consumer Knowledge and Sources of Information: Hungary in Transition. J. Acad. Mark. Sci. 2005, 33, 604-619. [CrossRef] 
106. Ziemba, E.; Eisenbardt, M.; Mullins, R.; Dettmer, S. Prosumers' Engagement in Business Process Innovation-The Case of Poland and the UK. Interdiscip. J. Inf. Knowl. Manag. 2019, 14, 119-143.

107. King, R.C.; Sen, R.; Xia, M. Impact of Web-Based e-Commerce on Channel Strategy. Int. J. Electron. Commer. 2004, 8, 103-130. [CrossRef]

108. Yadav, M.; Rahman, Z. Measuring consumer perception of social media marketing activities in e-commerce industry: Scale development \& validation. Telemat. Inf. 2017, 34, 1294-1307. [CrossRef]

109. Lee, S.Y.T.; Phang, C.D. Leveraging social media for electronic commerce in Asia: Research areas and opportunities. Electron. Commer. Res. Appl. 2014, 14, 145-149. [CrossRef]

110. Caiazza, R.; Bigliardi, B. Web marketing in agri-food industry: Challenges and opportunities. Trends Food Sci. Technol. 2020, 103, 12-19. [CrossRef]

111. Samoggia, A.; Riedel, B.; Ruggeri, A. Social media exploration for understanding food product attributes perception: The case of coffee and health with Twitter data. Br. Food J. 2020, 122, 3815-3835. [CrossRef]

112. Baruk, A.I. The effect of consumers' ethnocentric attitudes on their willingness for presumption. Heliyon 2019,5 , e02015. [CrossRef]

113. Sun, Y.; Gonzalez-Jimenez, H.; Wang, S. Examining the relationships between e-WOM, consumer ethnocentrism and brand equity. J. Bus. Res. 2020, 130, 564-573. [CrossRef]

114. Tomasi, S.; Li, X. Influences of Search Engine Optimization on Performance of SMEs. J. Electron. Commer. Organ. $2015,13,27-49$. [CrossRef]

115. Aul, V. Search engine optimization for Small and Medium Enterprises (SMEs). Educ. Econ. Community 2011, 1, 94-113.

116. James, L. Identifying the effect of Digital Marketing channels on the growth of SME in South Asia: A Case Study on Faheem Haydar Dealzmag. J. SA Bus. 2021, 1, 23-32.

117. Davcik, N.S.; Cardinali, S.; Sharma, P.; Cedrola, E. Exploring the role of international R\&D activities in the impact of tech-nological and marketing capabilities on SMEs' performance. J. Bus. Res. 2021, 128, 650-660.

118. Chechelski, P. Changes in food industry in poland under the impact of transnational corporations in the 21st century. Probl. Agric. Econ. 2017, 353, 50-71. [CrossRef]

119. Wardati, N.K.; Mahendrawathi, E.R. The Impact of Social Media Usage on the Sales Process in Small and Medium Enterprises (SMEs): A Systematic Literature Review. Procedia Comput. Sci. 2019, 161, 976-983. [CrossRef] 